\title{
Cultivar and Growing Location Effects on Fatty Acids, Minerals, and Sugars in Green Seeds of White Lupin (Lupinus albus L.)
}

\author{
Harbans L. Bhardwaj* and Anwar A. Hamama
}

Agricultural Research Station, Virginia State University, P.O. Box 9061, Petersburg, VA 23806 USA

\begin{abstract}
Evaluation of green immature seeds from ten cultivars of white lupin (Lupinus albus L., Fabaceae), grown in two locations in Virginia (USA) during two years, indicated that physiological mature but green white lupin seeds contained 33 percent protein and 7 oil on dry weight basis. Contents of C18:3, saturated, unsaturated, mono-unsaturated, and poly-unsaturated fatty acids in white lupin green seeds were $10,18,84,40$, and 42 percent of total oil, respectively. White lupin green seeds contained $0.39,1.34,0.20,0.37,0.21$, and 0.03 percent, dry weight basis, of $\mathrm{P}, \mathrm{K}, \mathrm{S}, \mathrm{Ca}, \mathrm{Mg}$, and $\mathrm{Na}$, respectively. White lupin green seeds contained $56,8,224,8,56$, and $22 \mathrm{mg} / \mathrm{kg} \mathrm{Fe}, \mathrm{Al}, \mathrm{Mn}, \mathrm{Cu}, \mathrm{Zn}$, and B, respectively. Contents of fructose, glucose, sucrose, raffinose, stachyose, verbascose, and total sugars in green white lupin seeds were $0.25,0.42,2.71,1.17,6.01,1.32$, and $11.98 \mathrm{~g} / 100 \mathrm{~g}$ meal, respectively. Growing locations significantly affected composition of green white lupin seeds whereas effects of cultivars were limited. White lupin green seeds compared well with green peas and vegetable soybean seeds. Results indicated that white lupin green seeds may have potential as human food.
\end{abstract}

Keywords: Lupinus albus L., Legumes, New crops, Nutritional quality.

\section{INTRODUCTION}

Mature white lupin (Lupinus albus L., Fabaceae) seeds have been used as food for over 3000 years around the Mediterranean and for as much as 6,000 years in the Andean highlands. White lupin, a cool-season legume plant native to the Mediterranean, North Africa, and North and South America, has been evaluated as a grain, forage, and green manure crop in Virginia and the mid-Atlantic region of the United States. Extensive research has resulted in development of winterhardy lines and a production system [1-6]. Additional research has laid the foundation for utilization of white lupin mature seeds as food [7]. Mature white lupin seeds produced in Virginia contain 32 to $43 \%$ protein with a mean of $37 \%$, 3 to $7 \%$ oil with a mean of $5 \%$, and 5 to $9 \%$ sugar with a mean of $7 \%$ [2].

White lupin is planted in September-October and matures in the June-July in the mid-Atlantic region of the USA. However, physiologically mature but green white lupin seeds could be available during April-May for use as a vegetable. This period is important given the lack of similar material for human consumption during this time period. If use of white lupin as a vegetable develops, it could boost the establishment of white lupin as an agronomic crop to provide highprotein grains for food and feed. White lupin green seeds could be an alternate source of green seeds for human consumption similar to the vegetable-type soybean which is receiving increasing attention by health-conscious consumers $[8,9]$. However, information about potential yield, chemical composition relative to nutritional quality of

*Address correspondence to this author at the Agricultural Research Station, Virginia State University, P.O. Box 9061, Petersburg, VA 23806 USA;

Tel: 804-524-6723; Fax: 804-524-5950; E-mail: hbhardwj@vsu.edu white lupin green seed is not available. Our objective was to characterize composition of white lupin green seeds.

\section{MATERIALS AND METHODS}

\section{Plant Material}

Ten cultivars of white lupin used in this study were provided by Auburn University (Alabama, USA). The nine lines with "L" prefix included in our studies originated from F8 generation of Auburn University's white lupin breeding Program and involved CH304 line as female parent and "Lunoble" and "XA100" as male parents. "Ludet" is a French cultivar of white lupin. All white lupin lines included in this study are considered "sweet" based on alkaloid contents.

\section{Production of Green Seeds}

Three replications of a Randomized Complete Block Design were used in this field study. Field experiments were conducted at two locations (Petersburg and Suffolk) in Virginia (USA) during 2005-06 and 2006-07 crop seasons. The Petersburg experiments were planted on 29 September 2005 and 13 October 2006 whereas Suffolk experiments were planted on 4 October 2005 and 17 October 2006. Each plot consisted of four rows. Approximately 100 seeds were planted in each row with a cone type manual planter at a depth of approximately $4 \mathrm{~cm}$. These plots received no fertilizer applications because the seeds were inoculated with a commercial bradyrhizobial inoculum for $\mathrm{N}$ fixation and the field sites were known to have high levels of $\mathrm{P}$ and $\mathrm{K}$. The soil types at Petersburg (Approximately $37^{\circ} 15^{\prime} \mathrm{N}$ and $077^{\circ}$ $\left.30.8^{\prime} \mathrm{W}\right)$ and Suffolk $\left(36^{\circ} 40^{\prime} \mathrm{N}\right.$ and $\left.76^{\circ} 46^{\prime} \mathrm{W}\right)$ were Abel sandy loam and Rains fine sandy loam, respectively. Petersburg location is characterized by sandy loam soils whereas Suffolk location is characterized by sandy soils. Contents $\left(\mathrm{mg} . \mathrm{kg}^{-1}\right)$ of $\mathrm{P}, \mathrm{K}, \mathrm{Mg}$, and $\mathrm{Ca}$ in Petersburg soil were 77, 54, 
68, and 395 whereas those in Suffolk soil were 19, 81, 22, and 470 , respectively. The $\mathrm{pH}$ and organic matter (\%) of Petersburg soil was 6.4 and 1.5 whereas that of Suffolk soil were 5.9 and 0.7 , respectively. Plots were manually kept free of weeds.

The green pods were harvested over several days during each season when the pods were still green but starting to turn yellow approximately mid May in both years. This stage of white lupin growth corresponds, in general terms, to physiological maturity (R6 stage) in soybean [10]. Green pods were separated from stems and were shelled manually to obtain green immature seeds.

\section{Analysis of Green Seed Composition}

Contents of $\mathrm{N}$ and various minerals were determined according to Association of Analytical Chemists (AOAC) methods [11] by A\&L Laboratory, Richmond, VA. Protein content was determined by multiplying $\mathrm{N}$ content with 6.25 . Oil was extracted from $2 \mathrm{~g}$ of ground seed at room temperature by homogenization for $2 \mathrm{~min}$ in $10 \mathrm{~mL}$ hexane/isopropanol (3:2, vol/vol) with a Biospec Model 985-370 Tissue Homogenizer (Biospec Products, Inc., Racine, WI) and centrifuged at $4000 \times \mathrm{g}$ for $5 \mathrm{~min}$, as previously described [12]. The oil extraction procedure was repeated three times for each sample to ensure full oil recovery. The hexane-lipid layer was washed and separated from the combined extract by shaking and centrifugation with $10 \mathrm{~mL}$ of $1 \%$ $\mathrm{CaCl} 2$ and $1 \% \mathrm{NaCl}$ in $50 \%$ methanol. The washing procedure was repeated, and the purified lipid layer was removed by aspiration and dried over anhydrous $\mathrm{Na} 2 \mathrm{SO} 4$. The oil percentage ( $\mathrm{g} / 100 \mathrm{~g}$ dry basis) was determined gravimetrically [3] after drying in a vacuum oven at $40^{\circ} \mathrm{C}$ and stored under $\mathrm{N} 2$ at $-10^{\circ} \mathrm{C}$ until analyzed. FAME (Fatty Acid Methyl Esters) were prepared by acid-catalyzed transestrification method as previously described [12]. The oil samples (5 mg) were vortexed with $2 \mathrm{~mL}$ sulfuric acid/methanol $(1: 99, \mathrm{vol} / \mathrm{vol})$ in $10-\mathrm{mL}$ glass vials containing a Teflon boiling chip. The open vials were placed in a heating block at $90^{\circ} \mathrm{C}$ until the sample volume was reduced to $0.5 \mathrm{~mL}$. After cooling to room temperature, $1 \mathrm{~mL}$ of hexane, followed by 1 $\mathrm{mL}$ of distilled water was added. The mixture was vortexed, and the upper hexane layer containing the FAME was then dried over anhydrous $\mathrm{Na} 2 \mathrm{SO} 4$. The hexane phase containing FAME was transferred to a suitable vial and kept under N2 at $0^{\circ} \mathrm{C}$ for $\mathrm{GC}$ analysis. Analyses of FAME were carried out as described by Hamama et al. [12]. A $1-\mu \mathrm{L}$ aliquot of FAME in hexane was injected into a SupelcoWax 10 capillary column $(25 \mathrm{~m} \times 0.25 \mathrm{~mm}$ i.d. and $0.25 \mu \mathrm{m}$ film thickness; Supelco, Inc., Bellefonte, PA) in a Varian model Vista 6000 gas chromatograph equipped with an FID (Varian, Sugar Land, TX). Helium was used as a carrier gas at 25 $\mathrm{cm} / \mathrm{s}$, with a split ratio of $1: 100$. The column temperature was isothermal at $210^{\circ} \mathrm{C}$. The injector and detector temperatures were 250 and $260^{\circ} \mathrm{C}$, respectively. A Spectra Physics Model 4290 Integrator (San Jose, CA) was used to determine relative concentrations of the detected FA. Peaks were identified by reference to the retention of FAME standards and quantitated by the aid of heptadecanoic acid (17:0) as an internal standard. The concentration of each FA was calculated as the percentage $(\mathrm{w} / \mathrm{w})$ of the total FA. Sugars were extracted from ground sample $(1 \mathrm{~g})$ and analyzed by HPLC following the methods optimized by Johansen et al. [13]. Sugars in the extracts were identified by comparing their retention times with standard sugars. For quantification, trehalose was used as internal standard and the sugar concentration was expressed as g/ $100 \mathrm{~g}$ oil-free meal.

All data were analyzed using version 9.1 of SAS [14] using ANOVA with 5 percent level of significance.

\section{RESULTS AND DISCUSSION}

Cultivar effects were significant (Table 1) for contents of most fatty acids, and five micro-nutrients $(\mathrm{S}, \mathrm{Ca}, \mathrm{Mg}, \mathrm{Cu}$, and $\mathrm{B}$ ) in white lupin green seeds. We attribute these results to inclusion of a limited number of cultivars in our study. We speculate that evaluations over a greater number of cultivars would show significance of cultivar effects for most nutritional quality traits. The content of omega-3 fatty acid (C18:3 - Linolenic acid), higher contents of this fatty acids are considered desirable for human nutrition, were highest in L2423 and Ludet cultivars and lowest in L2405, L2417, L2418, L2420, and L2430 cultivars. L2418 and L2420 cultivars had significantly higher content of unsaturated fatty acids and, thus, produced seeds with better nutritional quality (Table 2). The ratio of $\mathrm{C} 18: 2$ and $\mathrm{C} 18: 3$ also provided information indicating cultivar differences relative to nutritional quality of white lupin green seeds. Based on the observation that $1: 1$ to $4: 1$ ratio of n-6 and n-3 fatty acids is desirable for human health $[15,16]$, green seeds of L2423 and Ludet cultivars possessed desirable nutritional quality. $\mathrm{B}, \mathrm{Ca}, \mathrm{Mg}, \mathrm{Cu}$, and $\mathrm{S}$ contents of white lupin green seeds varied among the cultivars. Ludet cultivar had significantly higher contents of these micronutrients, except for the $\mathrm{Mg}$ content, over most other cultivars. Contents of fructose, glucose, sucrose, raffinose, stachyose, verbascose, and total sugars were not affected by cultivars.

Locations effects were, in many instances, significant for all traits of white lupin green seeds under consideration (Table 1) except for contents of oil, three fatty acids (C18:0, C16:1, C18:3), aluminum, and two long-chain sugars (Stachyose and Verbascose). Seeds produced at Petersburg location had higher contents of 23 traits whereas seed produced at Suffolk location had higher contents of 7 traits over the other location. It was interesting to note that the content of C18:3 (Omega 3 fatty acid), a fatty acid that is considered desirable in human nutrition, was similar (9.6 vs. 9.8 percent) in seed produced at both locations (Table 3). However, the content of C22:1 (Erucic acid), a fatty acid that is considered undesirable for human nutrition, was affected by the growing location and the seed produced at Petersburg location had significantly lower content of erucic acid (Table 3 ). The seed produced at Petersburg location also had significantly higher content of poly-unsaturated fatty acids as compared to those produced at Suffolk. Higher contents of polyunsaturated fatty acids are considered desirable for human nutrition. Ratio of C18:2 to C18:3 fatty acids is an important consideration in human nutrition. As intake of $n-6$ fatty acids has increased in developed countries, consumption of foods rich in n-3 fatty acids has steadily declined. Omega-3 fatty acids constitute a minuscule portion $(<1 \%)$ of the total fatty acids in U.S. food supply whereas the omega-6 fatty acids 
Table 1. Partial Analysis of Variance (Mean Squares) for Composition of Green Seeds of Ten White Lupin Lines Grown at Two Locations in Virginia

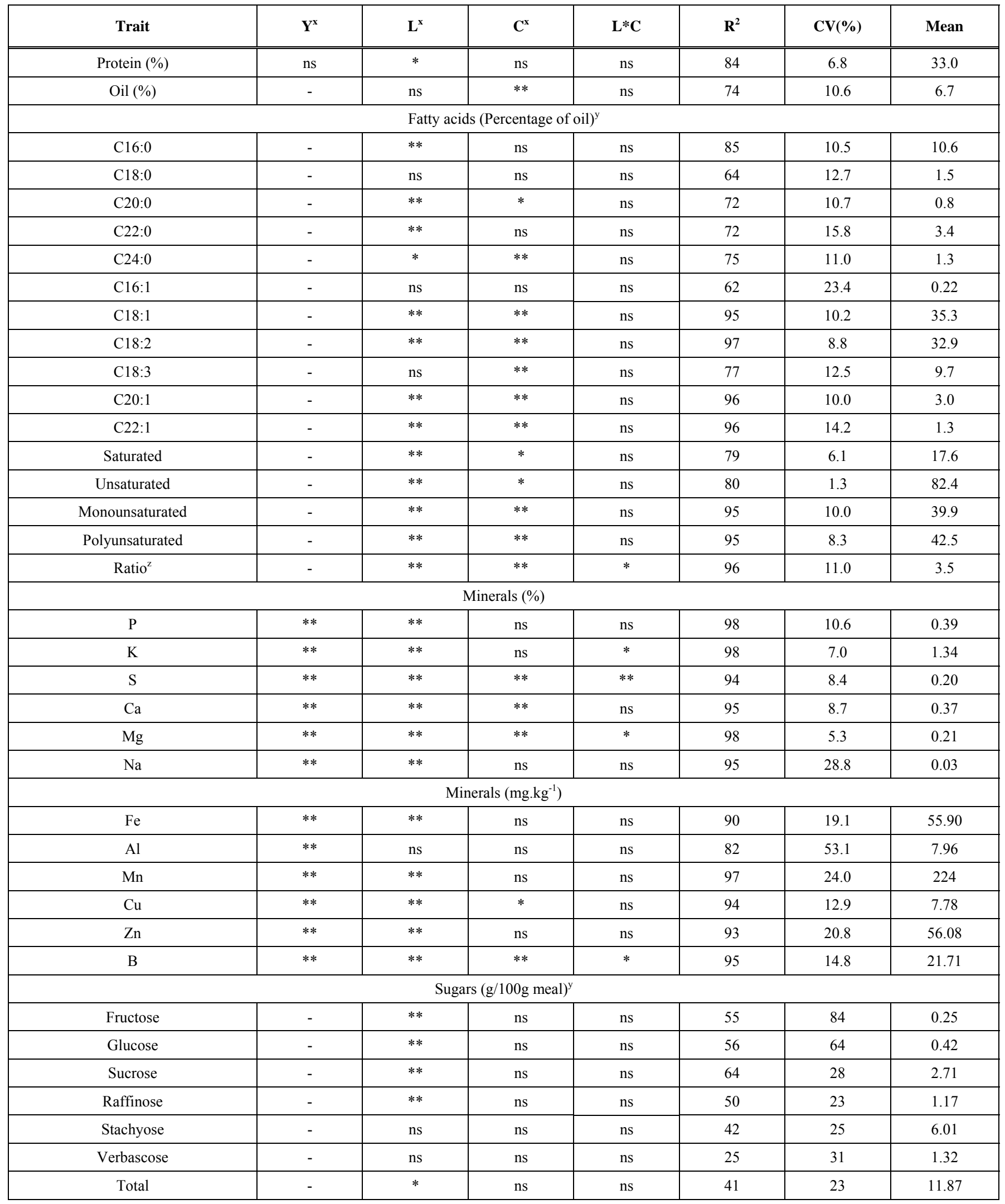

${ }^{\mathrm{x}} \mathrm{Y}=$ Year; $\mathrm{L}=$ Location; $\mathrm{C}=$ Cultivar.

${ }^{\mathrm{y}}$ Oil, fatty acids and sugars were analyzed only from seed produced during 2005-06 crop season.

${ }^{\mathrm{z}}$ Ratio between content of C18:2 and C18:3 fatty acids (Linoleic : Linolenic fatty acids).

${ }^{*, * *}$ Significant at 5 and $1 \%$ levels, respectively. ns : non-significant. 
Table 2. Cultivar Effects on Composition of Green Seeds of Ten White Lupin Lines Grown at Two Locations in Virginia

\begin{tabular}{|c|c|c|c|c|c|c|c|c|c|c|}
\hline Trait & L310 & L2405 & L2417 & L2418 & L2420 & L2423 & L2424 & L2425 & L2430 & LUDET \\
\hline Protein( $(\%)$ & $32.7 \mathrm{a}^{\mathrm{x}}$ & $33.3 \mathrm{a}$ & $32.8 \mathrm{a}$ & $33.1 \mathrm{a}$ & $32.0 \mathrm{a}$ & $33.0 \mathrm{a}$ & $33.2 \mathrm{a}$ & $34.0 \mathrm{a}$ & $33.6 \mathrm{a}$ & $32.0 \mathrm{a}$ \\
\hline Oil (\%) & $6.7 \mathrm{abc}$ & $7.3 \mathrm{ab}$ & $6.5 \mathrm{bc}$ & $6.8 \mathrm{abc}$ & $7.6 \mathrm{a}$ & $5.9 \mathrm{~cd}$ & $6.7 \mathrm{abc}$ & $6.4 \mathrm{bc}$ & $6.7 \mathrm{abc}$ & $5.3 \mathrm{~d}$ \\
\hline \multicolumn{11}{|c|}{ Fatty acids (Percentage of oil) } \\
\hline$C ! 6: 0$ & $10.7 \mathrm{a}$ & $10.0 \mathrm{a}$ & $10.7 \mathrm{a}$ & $10.1 \mathrm{a}$ & $9.8 \mathrm{a}$ & $10.8 \mathrm{a}$ & $10.4 \mathrm{a}$ & $11.6 \mathrm{a}$ & $10.7 \mathrm{a}$ & $11.0 \mathrm{a}$ \\
\hline C18:0 & $1.49 \mathrm{a}$ & $1.54 \mathrm{a}$ & $1.46 \mathrm{a}$ & $1.42 \mathrm{a}$ & $1.54 \mathrm{a}$ & $1.55 \mathrm{a}$ & $1.55 \mathrm{a}$ & $1.49 \mathrm{a}$ & $1.45 \mathrm{a}$ & $1.99 \mathrm{a}$ \\
\hline C20:0 & $0.78 \mathrm{abc}$ & $0.88 \mathrm{a}$ & $0.76 \mathrm{abc}$ & $0.72 b c$ & $0.81 \mathrm{ab}$ & $0.65 \mathrm{~cd}$ & $0.78 \mathrm{abc}$ & $0.75 \mathrm{abc}$ & $0.75 \mathrm{abc}$ & $0.58 \mathrm{~d}$ \\
\hline $\mathrm{C} 22: 0$ & $3.60 \mathrm{a}$ & $3.48 \mathrm{a}$ & $3.34 \mathrm{a}$ & $3.23 \mathrm{a}$ & $3.50 \mathrm{a}$ & $3.88 \mathrm{a}$ & $3.53 \mathrm{a}$ & $3.05 \mathrm{a}$ & $3.27 \mathrm{a}$ & $3.92 \mathrm{a}$ \\
\hline $\mathrm{C} 24: 0$ & $1.40 \mathrm{abc}$ & $1.28 \mathrm{bc}$ & $1.28 \mathrm{bc}$ & $1.30 \mathrm{bc}$ & $1.18 \mathrm{c}$ & $1.51 \mathrm{ab}$ & $1.19 \mathrm{c}$ & $1.56 \mathrm{a}$ & $1.28 \mathrm{bc}$ & $1.42 \mathrm{abc}$ \\
\hline C16:1 & $0.24 \mathrm{a}$ & $0.21 \mathrm{a}$ & $0.20 \mathrm{a}$ & $0.21 \mathrm{a}$ & $0.20 \mathrm{a}$ & $0.25 \mathrm{a}$ & $0.21 \mathrm{a}$ & $0.27 \mathrm{a}$ & $0.21 \mathrm{a}$ & $0.15 \mathrm{a}$ \\
\hline C18:1 & $35.4 \mathrm{ab}$ & $40.0 \mathrm{a}$ & $35.4 \mathrm{ab}$ & $35.2 \mathrm{ab}$ & $40.4 \mathrm{a}$ & $31.1 \mathrm{~B}$ & $36.4 \mathrm{ab}$ & $30.9 b$ & $36.2 \mathrm{ab}$ & $30.4 b$ \\
\hline C18:2 & $31.5 \mathrm{a}$ & $31.6 \mathrm{ab}$ & $32.9 \mathrm{ab}$ & $34.8 \mathrm{a}$ & $29.1 b$ & $33.5 \mathrm{ab}$ & $32.0 \mathrm{ab}$ & $35.8 \mathrm{a}$ & $33.1 \mathrm{ab}$ & $33.3 \mathrm{ab}$ \\
\hline C18:3 & $10.5 b c$ & $8.3 d$ & $8.5 \mathrm{~d}$ & $8.8 \mathrm{~cd}$ & $8.9 \mathrm{bcd}$ & $13.0 \mathrm{a}$ & $9.3 \mathrm{bcd}$ & $10.9 \mathrm{~b}$ & $8.9 \mathrm{bcd}$ & $13.3 \mathrm{a}$ \\
\hline $\mathrm{C} 20: 1$ & $3.11 \mathrm{abc}$ & $3.26 \mathrm{a}$ & $3.11 \mathrm{abc}$ & $3.01 \mathrm{a}-\mathrm{d}$ & $3.19 \mathrm{ab}$ & $2.64 \mathrm{~cd}$ & $3.14 \mathrm{abc}$ & $2.70 \mathrm{bcd}$ & $2.92 \mathrm{a}-\mathrm{d}$ & $2.55 \mathrm{~d}$ \\
\hline $\mathrm{C} 22: 1$ & $1.27 \mathrm{ab}$ & $1.54 \mathrm{a}$ & $1.36 \mathrm{ab}$ & $1.29 \mathrm{ab}$ & $1.46 \mathrm{a}$ & $1.12 \mathrm{~b}$ & $1.45 \mathrm{a}$ & $1.05 \mathrm{~b}$ & $1.25 \mathrm{ab}$ & $1.31 \mathrm{ab}$ \\
\hline SFA & $18.0 \mathrm{ab}$ & $17.2 \mathrm{ab}$ & $17.5 \mathrm{ab}$ & $16.8 \mathrm{~b}$ & $16.8 \mathrm{~b}$ & $18.4 \mathrm{ab}$ & $17.5 \mathrm{ab}$ & $18.5 \mathrm{ab}$ & $17.4 \mathrm{ab}$ & $19.0 \mathrm{a}$ \\
\hline UFA & $82.0 \mathrm{ab}$ & $82.8 \mathrm{ab}$ & $82.5 \mathrm{ab}$ & $83.2 \mathrm{a}$ & $83.2 \mathrm{a}$ & $81.6 \mathrm{ab}$ & $82.5 \mathrm{ab}$ & $81.5 \mathrm{ab}$ & $82.6 \mathrm{ab}$ & $81.0 \mathrm{~b}$ \\
\hline MUFA & $40.0 \mathrm{ab}$ & $43.0 \mathrm{a}$ & $41.0 \mathrm{ab}$ & $39.7 \mathrm{ab}$ & $45.2 \mathrm{a}$ & $35.1 \mathrm{~b}$ & $41.2 \mathrm{ab}$ & $34.9 \mathrm{~b}$ & $40.6 \mathrm{ab}$ & $34.4 b$ \\
\hline PUFA & $42.1 \mathrm{ab}$ & $39.8 b$ & $41.4 \mathrm{ab}$ & $43.6 \mathrm{ab}$ & $38.0 \mathrm{~b}$ & $46.6 \mathrm{a}$ & $41.3 \mathrm{ab}$ & $46.6 \mathrm{a}$ & $42.0 \mathrm{ab}$ & $46.6 \mathrm{a}$ \\
\hline Ratio $^{y}$ & $2.94 \mathrm{de}$ & $3.89 \mathrm{ab}$ & $3.94 \mathrm{a}$ & $4.03 \mathrm{a}$ & $3.24 \mathrm{~cd}$ & $2.64 \mathrm{e}$ & $3.46 \mathrm{a}-\mathrm{d}$ & $3.30 \mathrm{bcd}$ & $3.67 \mathrm{abc}$ & $2.50 \mathrm{e}$ \\
\hline \multicolumn{11}{|c|}{ Minerals $(\%)^{\mathrm{z}}$} \\
\hline $\mathrm{P}$ & $0.37 \mathrm{a}$ & $0.39 a$ & $0.39 \mathrm{a}$ & $0.40 \mathrm{a}$ & $0.40 \mathrm{a}$ & $0.41 \mathrm{a}$ & $0.40 \mathrm{a}$ & $0.40 \mathrm{a}$ & $0.39 \mathrm{a}$ & $0.38 \mathrm{a}$ \\
\hline $\mathrm{K}$ & $1.29 \mathrm{a}$ & $1.33 \mathrm{a}$ & $1.36 \mathrm{a}$ & $1.32 \mathrm{a}$ & $1.38 \mathrm{a}$ & $1.34 \mathrm{a}$ & $1.32 \mathrm{a}$ & $1.30 \mathrm{a}$ & $1.31 \mathrm{a}$ & $1.42 \mathrm{a}$ \\
\hline $\mathrm{S}$ & $0.20 \mathrm{a}$ & $0.20 \mathrm{a}$ & $0.21 \mathrm{a}$ & $0.20 \mathrm{a}$ & $0.21 \mathrm{a}$ & $0.18 \mathrm{~b}$ & $0.19 \mathrm{ab}$ & $0.20 \mathrm{ab}$ & $0.19 \mathrm{~b}$ & $0.20 \mathrm{ab}$ \\
\hline $\mathrm{Ca}$ & $0.35 \mathrm{~cd}$ & $0.35 \mathrm{~cd}$ & $0.37 \mathrm{~cd}$ & $0.35 \mathrm{~cd}$ & $0.40 \mathrm{ab}$ & $0.38 \mathrm{ab}$ & $0.35 \mathrm{~cd}$ & $0.35 \mathrm{~d}$ & $0.36 \mathrm{~cd}$ & $0.41 \mathrm{a}$ \\
\hline $\mathrm{Mg}$ & $0.20 \mathrm{~d}$ & $0.19 \mathrm{~d}$ & $0.20 \mathrm{~cd}$ & $0.20 \mathrm{~cd}$ & $0.21 b c$ & $0.23 \mathrm{a}$ & $0.20 \mathrm{~cd}$ & $0.21 \mathrm{bc}$ & $0.20 \mathrm{~cd}$ & $0.21 \mathrm{~b}$ \\
\hline $\mathrm{Na}$ & $0.03 \mathrm{a}$ & $0.03 \mathrm{a}$ & $0.03 \mathrm{a}$ & $0.03 \mathrm{a}$ & $0.03 \mathrm{a}$ & $0.03 \mathrm{a}$ & $0.03 \mathrm{a}$ & $0.03 a$ & $0.03 \mathrm{a}$ & $0.04 \mathrm{a}$ \\
\hline \multicolumn{11}{|c|}{ Minerals $\left(\mathrm{mg} \cdot \mathrm{kg}^{-1}\right)^{\mathrm{z}}$} \\
\hline $\mathrm{Fe}$ & $49.2 \mathrm{a}$ & $53.0 \mathrm{a}$ & $55.6 \mathrm{a}$ & $56.9 a$ & $57.2 \mathrm{a}$ & $56.3 \mathrm{a}$ & $57.4 \mathrm{a}$ & $57.3 \mathrm{a}$ & $60.3 \mathrm{a}$ & $55.9 \mathrm{a}$ \\
\hline $\mathrm{Al}$ & $7.77 \mathrm{a}$ & $7.64 a$ & $7.66 \mathrm{a}$ & $9.84 \mathrm{a}$ & $6.71 \mathrm{a}$ & $10.3 \mathrm{a}$ & $6.27 \mathrm{a}$ & $9.23 \mathrm{a}$ & $7.97 \mathrm{a}$ & $6.12 \mathrm{a}$ \\
\hline $\mathrm{Mn}$ & $209 a$ & $191 \mathrm{a}$ & $218 \mathrm{a}$ & $215 \mathrm{a}$ & $252 a$ & $243 a$ & $222 a$ & $204 a$ & $219 a$ & $265 a$ \\
\hline $\mathrm{Cu}$ & $7.68 \mathrm{bc}$ & $7.40 \mathrm{c}$ & $7.38 \mathrm{c}$ & $7.58 \mathrm{bc}$ & $7.95 \mathrm{abc}$ & $7.61 \mathrm{bc}$ & $8.42 \mathrm{ab}$ & $7.52 \mathrm{bc}$ & $7.50 \mathrm{bc}$ & $8.72 \mathrm{a}$ \\
\hline $\mathrm{Zn}$ & $62.1 \mathrm{a}$ & $49.6 \mathrm{a}$ & $51.5 \mathrm{a}$ & $53.9 \mathrm{a}$ & $59.9 \mathrm{a}$ & $61.4 \mathrm{a}$ & $54.0 \mathrm{a}$ & $54.8 \mathrm{a}$ & $53.0 \mathrm{a}$ & $60.5 \mathrm{a}$ \\
\hline B & $19.4 \mathrm{c}$ & $20.4 b c$ & $20.4 b c$ & $20.3 b c$ & $22.7 \mathrm{ab}$ & $24.1 \mathrm{a}$ & $22.8 \mathrm{ab}$ & $20.5 b c$ & $23.8 \mathrm{a}$ & $22.7 \mathrm{ab}$ \\
\hline \multicolumn{11}{|c|}{ Sugars $(\mathrm{g} / 100 \mathrm{~g}$ meal $)$} \\
\hline Fructose & $0.24 \mathrm{a}$ & $0.23 \mathrm{a}$ & $0.43 \mathrm{a}$ & $0.20 \mathrm{a}$ & $0.21 \mathrm{a}$ & $0.18 \mathrm{a}$ & $0.32 \mathrm{a}$ & $0.34 \mathrm{a}$ & $0.18 \mathrm{a}$ & $0.18 \mathrm{a}$ \\
\hline Glucose & $0.40 \mathrm{a}$ & $0.35 \mathrm{a}$ & $0.63 \mathrm{a}$ & $0.39 \mathrm{a}$ & $0.35 \mathrm{a}$ & $0.35 \mathrm{a}$ & $0.49 \mathrm{a}$ & $0.50 \mathrm{a}$ & $0.34 \mathrm{a}$ & $0.36 \mathrm{a}$ \\
\hline Sucrose & $2.93 \mathrm{a}$ & $2.82 \mathrm{a}$ & $2.66 \mathrm{a}$ & $3.04 \mathrm{a}$ & $2.71 \mathrm{a}$ & $2.83 \mathrm{a}$ & $2.20 \mathrm{a}$ & $2.65 \mathrm{a}$ & $2.80 \mathrm{a}$ & $2.44 \mathrm{a}$ \\
\hline Raffinose & $1.13 \mathrm{a}$ & $1.12 \mathrm{a}$ & $1.08 \mathrm{a}$ & $1.23 \mathrm{a}$ & $1.20 \mathrm{a}$ & $1.31 \mathrm{a}$ & $1.09 \mathrm{a}$ & $1.22 \mathrm{a}$ & $1.20 \mathrm{a}$ & $1.06 \mathrm{a}$ \\
\hline Stachyose & $6.16 \mathrm{a}$ & $6.06 \mathrm{a}$ & $5.91 \mathrm{a}$ & $5.93 a$ & $5.83 a$ & $7.12 \mathrm{a}$ & $5.52 \mathrm{a}$ & $5.71 \mathrm{a}$ & $6.25 \mathrm{a}$ & $5.65 \mathrm{a}$ \\
\hline Verbascose & $1.45 \mathrm{a}$ & $1.22 \mathrm{a}$ & $1.22 \mathrm{a}$ & $1.32 \mathrm{a}$ & $1.30 \mathrm{a}$ & $1.53 \mathrm{a}$ & $1.19 \mathrm{a}$ & $1.23 \mathrm{a}$ & $1.40 \mathrm{a}$ & $1.34 \mathrm{a}$ \\
\hline Total & $12.3 \mathrm{a}$ & $11.8 \mathrm{a}$ & $11.9 \mathrm{a}$ & $12.1 \mathrm{a}$ & $11.6 \mathrm{a}$ & $13.3 \mathrm{a}$ & $10.8 \mathrm{a}$ & $11.7 \mathrm{a}$ & $12.2 \mathrm{a}$ & $11.0 \mathrm{a}$ \\
\hline
\end{tabular}

${ }^{\mathrm{x}}$ Means followed by similar letters within rows are not different according to Duncan's Multiple Range Test at $5 \%$ level of significance.

${ }^{\mathrm{y}}$ Ratio between content of C18:2 and C18:3 fatty acids (Linoleic : Linolenic fatty acids).

${ }^{\mathrm{z}}$ Means over two years, two locations, and three replications. 
Table 3. Location Effects on Composition of Green Seeds of Ten White Lupin Lines Grown at Two Locations in Virginia

\begin{tabular}{|c|c|c|}
\hline Trait & Petersburg & Suffolk \\
\hline Protein(\%) & $33.5 \mathrm{a}^{\mathrm{x}}$ & $32.5 b$ \\
\hline Oil(\%) & $6.7 \mathrm{a}$ & $6.7 \mathrm{a}$ \\
\hline \multicolumn{3}{|c|}{ Fatty acids (Percentage of oil) } \\
\hline $\mathrm{C} 16: 0$ & $12.1 \mathrm{a}$ & $8.8 \mathrm{~b}$ \\
\hline $\mathrm{C} 18: 0$ & $1.46 \mathrm{a}$ & $1.55 \mathrm{a}$ \\
\hline $\mathrm{C} 20: 0$ & $0.72 b$ & $0.81 \mathrm{a}$ \\
\hline $\mathrm{C} 22: 0$ & $2.93 b$ & $3.97 \mathrm{a}$ \\
\hline $\mathrm{C} 24: 0$ & $1.38 \mathrm{a}$ & $1.29 \mathrm{~b}$ \\
\hline $\mathrm{C} 16: 1$ & $0.21 \mathrm{a}$ & $0.23 \mathrm{a}$ \\
\hline C18:1 & $25.7 \mathrm{~b}$ & $46.4 \mathrm{a}$ \\
\hline $\mathrm{C} 18: 2$ & $43.0 \mathrm{a}$ & $21.1 \mathrm{~b}$ \\
\hline $\mathrm{C} 18: 3$ & $9.59 \mathrm{a}$ & $9.76 \mathrm{a}$ \\
\hline C20:1 & $2.14 \mathrm{~b}$ & $4.01 \mathrm{a}$ \\
\hline $\mathrm{C} 22: 1$ & $0.71 b$ & $2.01 \mathrm{a}$ \\
\hline SFA & $18.6 \mathrm{a}$ & $16.4 \mathrm{~b}$ \\
\hline UFA & $81.4 \mathrm{~b}$ & $83.6 \mathrm{a}$ \\
\hline MUFA & $28.8 b$ & $52.7 \mathrm{a}$ \\
\hline PUFA & $52.6 \mathrm{a}$ & $30.9 b$ \\
\hline Ratio $^{y}$ & $4.62 \mathrm{a}$ & $2.16 \mathrm{~b}$ \\
\hline \multicolumn{3}{|c|}{ Minerals $(\%)^{\mathrm{z}}$} \\
\hline $\mathrm{P}$ & $0.48 \mathrm{a}$ & $0.31 \mathrm{~b}$ \\
\hline $\mathrm{K}$ & $1.41 \mathrm{a}$ & $1.26 \mathrm{~b}$ \\
\hline S & $0.22 \mathrm{a}$ & $0.18 \mathrm{~b}$ \\
\hline $\mathrm{Ca}$ & $0.41 \mathrm{a}$ & $0.33 \mathrm{~b}$ \\
\hline $\mathrm{Mg}$ & $0.21 \mathrm{a}$ & $0.20 \mathrm{~b}$ \\
\hline $\mathrm{Na}$ & $0.04 \mathrm{a}$ & $0.02 \mathrm{~b}$ \\
\hline \multicolumn{3}{|c|}{ Minerals $\left(\mathrm{mg} \cdot \mathrm{kg}^{-1}\right)^{\mathrm{z}}$} \\
\hline $\mathrm{Fe}$ & $63.7 \mathrm{a}$ & $48.1 \mathrm{~b}$ \\
\hline $\mathrm{Al}$ & $8.24 \mathrm{a}$ & $7.7 \mathrm{a}$ \\
\hline $\mathrm{Mn}$ & $303 \mathrm{a}$ & $144 \mathrm{~b}$ \\
\hline $\mathrm{Cu}$ & $9.17 \mathrm{a}$ & $6.38 \mathrm{~b}$ \\
\hline $\mathrm{Zn}$ & $61.9 \mathrm{a}$ & $50.2 \mathrm{~b}$ \\
\hline $\mathrm{B}$ & $25.7 \mathrm{a}$ & $17.8 \mathrm{~b}$ \\
\hline \multicolumn{3}{|c|}{ Sugars (g/100g meal) } \\
\hline Fructose & $0.35 \mathrm{a}$ & $0.16 b$ \\
\hline Glucose & $0.54 \mathrm{a}$ & $0.29 b$ \\
\hline Sucrose & $3.23 \mathrm{a}$ & $2.19 b$ \\
\hline Raffinose & $1.33 \mathrm{a}$ & $1.00 \mathrm{~b}$ \\
\hline Stachyose & $5.87 \mathrm{a}$ & $6.15 \mathrm{a}$ \\
\hline Verbascose & $1.37 \mathrm{a}$ & $1.27 \mathrm{a}$ \\
\hline Total & 12.7 & $11.1 \mathrm{~b}$ \\
\hline
\end{tabular}

${ }^{\times}$Means followed by similar letters within rows are not different according to Duncan's Multiple Range Test at $5 \%$ level of significance.

${ }^{\mathrm{y}}$ Ratio between content of C18:2 and C18:3 fatty acids (Linoleic : Linolenic fatty acids).

${ }^{\mathrm{z}}$ Means over two years, two locations, and three replications. 
(Linoleic acid, 18:2) constitute a significant majority [15, 16]. The ratio of n-6 and n-3 fatty acids is important for human health and should be $1: 1$ to $4: 1$ whereas in the Western diet it is now estimated to be $10: 1$ to $30: 1[16,17]$. The white lupin green seeds produced at both locations meet this desirability ratio criterion. On the positive side, seeds produced at Petersburg also had higher contents of fructose, glucose, and sucrose, and total sugars over those produced at Suffolk (Table 3). Seeds produced at Petersburg location contained higher contents of calcium, iron, and zinc, therefore, Petersburg location was identified as a desirable location for production of white lupin green seeds for human consumption.

Even though our results indicate Petersburg location to be a desirable location, we suggest that quality of white lupin green seeds may change based on the specific soil characteristics given that most traits in crops are dependent upon soil characteristics, plant genotype, and an interaction between these two factors in addition to climatic conditions. The specific effect of a given soil on nutritional quality of white lupin green seeds will be hard to characterize, however, our results suggest that presence of higher contents of organic matter (sandy loam soil being better than sandy soil), P, and $\mathrm{Mg}$ and lower contents of $\mathrm{K}$ and $\mathrm{Ca}$ might be conducive for production of white lupin green seeds with higher contents of poly-unsaturated fatty acids, sugars, and minerals. However, this observation is based on limited data and would need to be verified in the future.

We observed that Petersburg location is characterized by sandy loam soils whereas Suffolk location is characterized by sandy soils. Contents $\left(\mathrm{mg} \cdot \mathrm{kg}^{-1}\right)$ of $\mathrm{P}, \mathrm{K}, \mathrm{Mg}$, and $\mathrm{Ca}$ in Petersburg soil were $77,54,68$, and 395 whereas those in Suffolk soil were $19,81,22$, and 470 , respectively. The $\mathrm{pH}$ and organic matter (\%) of Petersburg soil was 6.4 and 1.5 whereas that of Suffolk soil were 5.9 and 0.7 , respectively. Additionally, ambient temperatures at Petersburg location are cooler than those at Suffolk locations. Based on historical data, Petersburg location (Average lowest, average highest, and average mean temperatures of 18,72 , and $46^{\circ} \mathrm{F}$, respectively) is cooler than the Suffolk location (Average lowest, average highest, and average mean temperatures of 15, 79, and $47^{\circ} \mathrm{F}$, respectively). We speculate that these differences contribute towards differential composition of white lupin green seeds. Our results indicated that cultivar effects for several nutritional quality traits were not significant, however, we are not suggesting that only weather and soil conditions affect lupin seed composition. Rather, the composition of white lupin seed is expected to be determined by agroclimatic and host plant genetic factors.

\section{White Lupin, Peas, and Soybean Green Seeds}

The protein content of white lupin green seeds was higher than that of green peas and vegetable soybean (Table 4) whereas oil content was greater than in green peas and similar to that in soybean. In general, contents of fatty acids in green white lupin seeds were similar or greater than those of green peas and vegetable soybean except for content of erucic acid which was non-existent in peas. A positive observation was related to contents of iron and zinc - white lupin green seeds had considerably higher contents than peas and vegetable soybean (Table 4). White lupin green seeds had higher total sugar content than peas whereas sucrose content was greater in peas. Both fructose and glucose content were higher in white lupin green seeds as compared to those in peas indicating that green white lupin seeds might be sweeter than green peas.

The protein content of white lupin green seeds (Approximately 33 percent) was similar to that in vegetable soybean (Approximately 36 percent [18]; 38 percent: [19]) and higher than green peas (Approximately 5 percent, [20]). Vegetable soybean, also known as Edamame, is the term used to describe physiologically mature but immature green seed of soybean [8]. One advantage of using white lupin immature fresh seeds is that these seeds become available in April-May whereas fresh vegetable soybean (Edamame) becomes available in August-September.

Based on the results from our current studies and considerable yield potential of white lupin green seeds $(18 \mathrm{Mg} / \mathrm{ha}-$ [9] in comparison to approximately $10 \mathrm{Mg} / \mathrm{ha}$ for Edamame [18], we suggest that white lupin green seeds may have potential as a human food crop. The real potential of white lupin green seeds as human food would depend upon consumer acceptability based on taste tests and lack of antinutritional traits components. The lines included in our studies were developed by Auburn University and are classified as sweet. We speculate that white lupin can provide a source of green seeds similar to those from green peas and vegetable soybean [18]. Even though use of mature soybean seeds as human food is limited, use of vegetable soybean (Physiologically mature but green soybean seeds) for human consumption has been reported [18].

Several reports $[1,2,3$, and 4$]$ have indicated use of mature white lupin seeds as human food but we were unable to find any reports related to use of immature green white lupin seeds as human food. We believe that white lupin green seeds have potential for human consumption similar to the vegetable soybean (Edamame) and green peas. However, lupin seeds are known to contain anti-nutritional factors such as alkaloids, phytate, and oligosaccharides [21, 22]. Lupin seeds are generally classified as "sweet" or "bitter" depending upon the content of alkaloids which can vary from 0.01 to $4 \%$ [23]. The bitter seeds contain quinolizidine alkaloids such as lupanine, lupinine, and sparteine. The presence of these alkaloids limits the use of lupin seeds as food and feed [24]. The Australian standard is $0.02 \%$ as the upper alkaloid content limit for sweet lupins [25]. Before the development of sweet lupins, the bitter lupin seeds were debittered by soaking in running water and cooking/toasting [26]. The lupin breeding work of Sengbusch in Germany during 19281929 laid the foundation for development of sweet lupin cultivars. Currently sweet cultivars are available in all four lupin species that are being used as agricultural crops in the world [25]. All cultivars used in our studies were classified as sweet. However, information about presence/and concentration of anti-nutritional factors in green seeds is needed before use of white lupin green seeds can be recommended for human consumption. Such studies will be worthwhile given the increasing interest among consumers for novel plant products as evidenced by growing popularity of vegetable soybean. 
Table 4. Composition of Green Raw Seeds of White lupin, Peas, and Soybean

\begin{tabular}{|c|c|c|c|}
\hline Trait & White lupin ${ }^{x}$ & Peas $^{\mathrm{y}}$ & Soybean $^{y}$ \\
\hline Protein(\%) & 33.0 & 5.42 & 12.95 \\
\hline Oil (\%) & 6.7 & 0.40 & 6.80 \\
\hline \multicolumn{4}{|c|}{ Fatty acids (Percentage of oil) } \\
\hline $\mathrm{C} 16: 0$ & 10.6 & 16.00 & 8.38 \\
\hline $\mathrm{C} 18: 0$ & 1.5 & 1.75 & 3.09 \\
\hline $\mathrm{C} 20: 0$ & 0.8 & na & na \\
\hline $\mathrm{C} 22: 0$ & 3.4 & na & na \\
\hline $\mathrm{C} 24: 0$ & 1.3 & na & na \\
\hline C16:1 & 0.2 & 0.00 & 0.16 \\
\hline C18:1 & 35.3 & 8.75 & 18.56 \\
\hline $\mathrm{C} 18: 2$ & 32.9 & 38.00 & 41.51 \\
\hline $\mathrm{C} 18: 3$ & 9.7 & 8.75 & 5.53 \\
\hline C20:1 & 3.0 & 0.00 & 0.16 \\
\hline $\mathrm{C} 22: 1$ & 1.3 & 0.00 & na \\
\hline SFA & 17.6 & 17.75 & 11.56 \\
\hline UFA & 82.4 & 82.25 & 88.44 \\
\hline MUFA & 39.9 & 8.75 & 18.88 \\
\hline PUFA & 42.5 & 46.75 & 47.06 \\
\hline Ratio $^{z}$ & 3.5 & 4.34 & 7.51 \\
\hline \multicolumn{4}{|c|}{ Minerals (\%) } \\
\hline $\mathrm{P}$ & 0.4 & 1.08 & 1.94 \\
\hline $\mathrm{K}$ & 1.3 & 2.44 & 6.20 \\
\hline S & 0.2 & na & na \\
\hline $\mathrm{Ca}$ & 0.4 & 0.25 & 0.20 \\
\hline $\mathrm{Mg}$ & 0.2 & 0.33 & 0.65 \\
\hline $\mathrm{Na}$ & 0.0 & 0.05 & 0.15 \\
\hline \multicolumn{4}{|c|}{ Minerals (mg.kg ${ }^{-1}$ ) } \\
\hline $\mathrm{Fe}$ & 55.9 & 14.7 & 35.5 \\
\hline $\mathrm{Al}$ & 8.0 & na & na \\
\hline $\mathrm{Mn}$ & 224 & 4.10 & 5.47 \\
\hline $\mathrm{Cu}$ & 7.8 & 1.76 & 1.28 \\
\hline $\mathrm{Zn}$ & 56.1 & 12.4 & 9.90 \\
\hline $\mathrm{B}$ & 21.7 & na & na \\
\hline \multicolumn{4}{|c|}{ Sugars (g/100g meal) } \\
\hline Fructose & 0.2 & 0.39 & na \\
\hline Glucose & 0.4 & 0.12 & na \\
\hline Sucrose & 2.7 & 4.99 & na \\
\hline Raffinose & 1.2 & na & na \\
\hline Stachyose & 6.0 & na & na \\
\hline Verbascose & 1.3 & na & na \\
\hline Total & 11.9 & 5.67 & na \\
\hline
\end{tabular}

${ }^{\mathrm{x}}$ Values are from current study.

${ }^{\mathrm{y}}$ Values are from USDA, 2012.

${ }^{\mathrm{Z}}$ RATIO BETWEEN CONTENT OF C18:2 AND C18:3 FATTY ACIDS (LINOLEIC : LINOLENIC FATTY ACIDS). 


\section{ACKNOWLEDGEMENTS}

Contribution of Virginia State University, Agricultural Research Station, Journal Article Series No. 297. Use of any trade names or vendors does not imply approval to the exclusion of other products or vendors that may also be suitable. Funds from USDA-CSREES (Now NIFA) 1890 Institutions Capacity Building Grants Program were used to support this study. Authors thankfully acknowledge assistance of Dr. Edzard van Santen, Auburn University, Auburn, Alabama (USA) for providing seeds of white lupin lines included in this report.

\section{CONFLICT OF INTEREST}

No conflicts of interest exist for the contents of this manuscript.

\section{REFERENCES}

[1] Bhardwaj HL. Evaluation of lupin as a new food/feed crop in the US mid-Atlantic region. In: Janick J, Whipkey A, Eds. Trends in new crops and new uses.USA: ASHS Press 2002; pp.115-9.

[2] Bhardwaj HL, Hamama AA, Merrick LC. Genotypic and environmental effects on lupin seed composition. Plant Foods Human Nutr 1998; 53:1-13.

[3] Bhardwaj HL, Hamama AA, van Santen E. Fatty acids and oil content in white lupin seed as affected by production practices. J Am Oil Chem Soc 2004a; 81:1035-8.

[4] Bhardwaj HL, Hamama AA, van Santen E. White lupin performance and nutritional quality as affected by planting date and row spacing. Agron J 2004b; 96: 580-3.

[5] Bhardwaj HL, Starner DE, van Santen E. Preliminary evaluation of white lupin (Lupinus albus L.) as a forage crop in the mid-Atlantic region of the United States of America. J Agric Sci 2010; 2:13-7.

[6] Robinson KO, Beyene DA, van Berkum P, Knight-Mason R, Bhardwaj HL. Variability in plant-microbe interaction between Lupinus lines and Bradyrhizobium strains. Plant Sci 2000; 159(2): 257-64.

[7] Hamama AA, Bhardwaj HL. Phytosterols, triterpine alcohols, and phospholipids in seed oil from white lupin. J Am Oil Chem Soc 2004; 81:1039-44

[8] Brar GS, Carter TF, Jr. Soybean, Glycine max (L.) Merrill. In Kalloo G, Bergh BO; Eds. Genetic improvement of vegetable crops. New York: Pergamon Press 1993; pp. 427-63.

[9] Bhardwaj HL, Hamama AA. Cultivar and growing location effects on white lupin immature green seeds. J Agric Sci 2012; 4:135-8.
[10] Fehr WR, Caviness CE, Burmood DT, Pennington JS. Stage of development descriptions for soybeans, Glycine max (L.) Merrill. Crop Sci 1971; 11: 929-31.

[11] AOAC. Official methods of analysis. $16^{\text {th }}$ ed. Arlington, VA: Association of Analytical Chemists 1995

[12] Hamama AA, Bhardwaj HL, Starner DE. Genotype and growing location effects on phytosterols in canola oil. J Am Oil Chem Soc 2005; 80:1121-6.

[13] Johansen HN, Glitsø V, Knudsen KEN. Influence of extraction solvent and temperature on the quantitative determination of oligosaccharides from plant materials by high-performance liquid chromatography. J Agric Food Chem 1996; 44: 1470-4.

[14] SAS. SAS System for Windows; SAS Institute, Inc., Cary, NC 2002.

[15] Raper NR, Cronin FJ, Exler J. Omega-3 fatty acid content of the US food supply. J Am Coll Nutr 1992; 11(3): 304-8.

[16] Watkins C. Fundamental fats. Inform 2004; 15(10): 638-40.

[17] Schmidt MA. Brain-building nutrition, the healing power of fats and oils. $2^{\text {nd }}$ ed. Berkeley, California: North Atlantic Books 2001.

[18] Rao MSS, Bhagsari AS, Mohamed AI. Fresh green seed yield and seed nutritional traits of vegetable soybean genotypes. Crop Sci 2002; 42: 1950-8.

[19] Mebrahtu T. Analysis of nutritional contents in vegetable soybeans. J Crop Impror 2008; 21:157-70.

[20] USDA. U.S department of agriculture, Agricultural Research Service 2012. USDA National Nutrient Database for Standard Reference, Release 24 2012; Nutrient Data Laboratory Home Page [online]. Available at: http://ndb.nal.usda.gov/ [Accessed $20124^{\text {th }}$ June].

[21] Dagnia SG, Petterson DS, Flanagan FV. Germination alters the nutritional value of lupin seed. J Sci Food Agric 1992; 60: 419-23.

[22] Muzquiz M, Cuadrado C, Ayet G, Cuadra C, Burbano C, Osagie A. Variation of alkaloid components of lupin seeds in 49 genotypes of Lupinus albus L. from different countries and locations. J Agric Food Chem 1994; 42:1447-50.

[23] Allen JG. Toxins and lupinosis. In: Gladstones JS, Atkins C, Hamblin J, Eds. Lupins as crop plants: biology, production, and utilization. UK: CAB International 1998; pp. 411-35.

[24] Muzquiz M, de la Cuadra C, Cuadrado C, Burbano C, Calvo R. Herbicide-like effect of Lupinus alkaloids. Ind Crops Prod 1994; 2 : 273-80.

[25] Cowling WA, Huyghe C, Swiecki W. Lupin Breeding. In: Gladstones JS, Atkins C, Hamblin J, Eds. Lupins as Crop Plants: biology, production, and utilization. UK: CAB International 1998; pp. 437-54.

[26] Aguilera JM, Trier A. The revival of lupin. Food Technol 1978; 32: $70-6$

(C) Bhardwaj and Hamama; Licensee Bentham Open.

This is an open access article licensed under the terms of the Creative Commons Attribution Non-Commercial License (http://creativecommons.org/licenses/by-nc/3.0/) which permits unrestricted, non-commercial use, distribution and reproduction in any medium, provided the work is properly cited. 